\title{
Drought, pod yield, pre-harvest Aspergillus infection and aflatoxin contamination on peanut in Niger
}

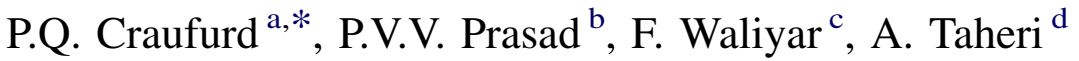 \\ ${ }^{a}$ The University of Reading, Plant Environment Laboratory, Cutbush Lane, Shinfield, Reading RG2 9AF, UK \\ ${ }^{\mathrm{b}}$ Department of Agronomy, Kansas State University, 3708 Throckmorton Hall, Manhattan, KS 66506, USA \\ ${ }^{\mathrm{c}}$ International Crops Research Institute for the Semi-Arid Tropics, Patancheru, Andhra Pradesh 502 324, India \\ ${ }^{\mathrm{d}}$ President, Gorgan University of Agricultural Sciences and Natural Resources, Shahid Beheshti Avenue, Gorgan 49138-15739, Iran
}

Received 16 December 2004; received in revised form 2 December 2005; accepted 3 December 2005

\begin{abstract}
Soil moisture and soil temperature affect pre-harvest infection with Aspergillus flavus and production of aflatoxin. The objectives of our field research in Niger, West Africa, were to: (i) examine the effects of sowing date and irrigation treatments on pod yield, infection with $A$. flavus and aflatoxin concentration; and (ii) to quantify relations between infection, aflatoxin concentration and soil moisture stress. Seed of an aflatoxin susceptible peanut cv. JL24 was sown at two to four different sowing dates under four irrigation treatments (rainfed and irrigation at 7, 14 and 21 days intervals) between 1991 and 1994, giving 40 different 'environments'. Average air and soil temperatures of $28-34{ }^{\circ} \mathrm{C}$ were favourable for aflatoxin contamination. CROPGRO-peanut model was used to simulate the occurrence of moisture stress. The model was able to simulate yields of peanut well over the 40 environments $\left(r^{2}=0.67\right)$. In general, early sowing produced greater pod yields, as well as less infection and lower aflatoxin concentration. There were negative linear relations between infection $\left(r^{2}=0.62\right)$ and the average simulated fraction of extractable soil water (FESW) between flowering and harvest, and between aflatoxin concentration $\left(r^{2}=0.54\right)$ and FESW in the last 25 days of pod-filling. This field study confirms that infection and aflatoxin concentration in peanut can be related to the occurrence of soil moisture stress during pod-filling when soil temperatures are near optimal for A. flavus. These relations could form the basis of a decisionsupport system to predict the risk of aflatoxin contamination in peanuts in similar environments.
\end{abstract}

(C) 2005 Elsevier B.V. All rights reserved.

Keywords: Aspergilus flavus; Aflatoxin; Peanut; Groundnut; Drought; Crop simulation modelling

\section{Introduction}

Peanut is an important crop in Niger, even though growing seasons are short and variable, and drought and high soil temperatures are common (Ntare and Williams, 1998). Aflatoxins are toxic, carcinogenic, teratogenic and immunosuppressive substances (Turner et al., 2000; Wild and Hall, 2000; Hall and Wild, 2003) produced when toxigenic strains of the fungi Aspergillus flavus Link. ex Fries and A. parasiticus Speare grow on peanuts and many other agricultural commodities. Aflatoxin concentration is the most important quality problem in peanuts worldwide with serious health implications for humans as well as livestock

\footnotetext{
* Corresponding author. Tel.: +44 118 9883000; fax: +44 1189885491. E-mail address: p.q.craufurd@ reading.ac.uk (P.Q. Craufurd).
}

(D'Mello, 2003; Bhat and Vasanthi, 2003; Gong et al., 2003; Waliyar et al., 2003a). For example, the majority of children tested in a recent study in West Africa who had detectable aflatoxin levels in their blood were stunted and under weight (Gong et al., 2003).

Infection of peanut by Aspergillus occurs under both preharvest and post-harvest conditions. Pre-harvest infection by Aspergillus and consequent aflatoxin concentration is more important in the semi-arid tropics, especially when drought occurs in the last 20-40 days of the season (e.g. Cole et al., 1989; Sanders et al., 1993). In a series of experiments using controlled soil temperature and soil water facilities, Cole and his co-workers (Cole et al., 1985, 1989; Dorner et al., 1989) have shown that pre-harvest contamination requires a drought period of 30-50 days and a mean soil temperature in the podding zone of $29-31{ }^{\circ} \mathrm{C}$. Drought in the absence of 
high soil temperature does not result in contamination. Shorter periods of drought ( $<20$ days), and drought early or late in the season, also result in lower concentrations of aflatoxin (and see Azaizeh et al., 1989). Similarly, soil temperatures in the pod zone, not the root zone, cooler or warmer than $29-31{ }^{\circ} \mathrm{C}$ also result in less aflatoxin concentration (Blankenship et al., 1984; Cole et al., 1989), even if a drought is imposed. However, these relations have not been verified under field conditions in West Africa where aflatoxin is major problem.

The work of Cole and his co-workers does, nonetheless, provide a sound basis for predicting aflatoxin contamination, or at least the risk of aflatoxin concentration above permissible limits (e.g. $>10 \mu \mathrm{g} \mathrm{kg}^{-1}$ ), if water deficit and soil temperature data are available. Of course these data are more often than not available for experiments, and certainly not available for the larger geographical areas over which there would be a risk from aflatoxin contamination. Therefore, crop simulation models, whether on a point (experiment, field; e.g. DSSAT) or pixel (district, region; e.g. GLAM) scale will be needed to estimate water deficit and soil temperature (Boote et al., 1998; Challinor et al., 2004). DSSAT-CROPGRO-peanut is a process oriented, mechanistic crop growth simulation model that simulates daily water balance, soil temperatures, and plant water deficits in response to weather inputs, soil characteristics, plant growth characteristics and crop management practices (Boote et al., 1998). This model has been successfully used to simulate soil water balance and fraction of extractable soil water (FESW), which is strongly related to physiological activity (Sinclair et al., 1987), for sandy soils in West Africa (Naab et al., 2004) and India (Singh et al., 1994). CROPGRO-peanut is particularly suited to predicting aflatoxin as it 'grows' cohorts of pods, allowing temporal effects on individual pods to be modelled and accumulated. If observed field values for infection and contamination can be quantitatively related to simulated values of FESW or water deficit from calibrated models, then these relations could form the basis of decisionsupport system to predict the occurrence or risk of aflatoxin contamination in peanut.

The overall aim of the work reported here was to examine whether measured A. flavus infection and aflatoxin concentration in the field in Niger, West Africa, could be predicted from simulated values of FESW, and hence form the basis of a risk model. Waliyar et al. (2003) grew four peanut cultivars at different sowing dates and levels of irrigation in each of 4 years at Sadore in Niger, West Africa and measured A. flavus infection, aflatoxin concentration, and pod yield. The objectives of this study were, therefore: (i) to examine the effects of year, sowing date and irrigation treatment (giving 40 different 'environments') on pod yield, A. flavus infection and aflatoxin concentration in a susceptible peanut cultivar, JL24 grown in the field; and (ii) to quantify relations between observed values of $A$. flavus infection and aflatoxin concentration with simulated soil moisture or drought stress (FESW).

\section{Materials and methods}

Experiments were carried out at the ICRISAT Sahelian Centre, Sadore, Niger $\left(13^{\circ} 15^{\prime} \mathrm{N}, 2^{\circ} 17^{\prime} \mathrm{E}\right)$ between 1991 and 1994. The soil at Sadore is classified as Psammentic Paleustalf (West et al., 1984) comprising 93\% sand. The soil moisture holding capacity in the root zone (top $60 \mathrm{~cm}$ ) is $44 \mathrm{~mm}$ (West et al., 1984). Sadore has a short growing season averaging 90 days with a long-term (1931-90) annual rainfall of $545 \mathrm{~mm}$ (Sivakumar et al., 1993). The experiments were situated within $500 \mathrm{~m}$ of the research station weather station.

Four cultivars were grown in each experiment (described below and see Waliyar et al. (2003b) for full details) but only results from one cultivar, JL24, are presented here as the overall aim was establish relations between infection/ contamination and drought (FESW), rather than genotypic differences in these relations; also genetic model coefficients for these genotypes were not available. JL24 is a short duration Spanish cultivar susceptible to Aspergillus infection and aflatoxin contamination.

\subsection{Experimental design and cultural practices}

In 1991, the experimental design was a randomised complete block in a split-plot arrangement with three replications. Four levels of irrigation (7, 14, and 21 days intervals and rainfed [no irrigation]) were used as main plots. At each irrigation, $20 \mathrm{~mm}$ of water was applied using sprinkler irrigation. There were four dates of sowing (sowing with the onset of rain, followed by sowing every 10 days thereafter) as subplots. In 1992, 1993 and 1994 the same experimental design was used except that only two dates of sowing (sowing with the onset of rain, and sowing 15 days later) were used. The plot size was $3.5 \times 5.0 \mathrm{~m}$ (seven rows of $5 \mathrm{~m}$ ) with spacing of $50 \mathrm{~cm}$ between rows and $10 \mathrm{~cm}$ within the row $(20$ plants $\mathrm{m}^{-2}$ ). Irrigation treatments were buffered by a $5 \mathrm{~m}$ strip.

Before planting, fields were prepared using an animal drawn plough and broadcast with $40 \mathrm{~kg} \mathrm{ha}^{-1}$ of $\mathrm{P}_{2} \mathrm{O}_{5}$. At planting seeds were treated with Thioral (25\% heptachlore and $25 \%$ Thiram) at the rate of $3 \mathrm{~g} \mathrm{~kg}^{-1}$ of seed. Seeds were hand planted. During the cropping season one to three handweedings were carried out using local implements. In this environment groundnut experiments are usually treated with carbofuran to control nematodes, which cause variable growth (Sharma et al., 1992; Waliyar et al., 1992). However, carbofuran was not applied in these experiments in case it affected A. flavus.

Plants were hand harvested at full maturity (95-100 d). All the pods (mature and immature) were removed from plants and immediately brought to the crop-work area where they were dried in mesh trays at ambient air temperatures of 30 to $35^{\circ} \mathrm{C}$. Under these conditions pods 
dry to $<10 \%$ kernel moisture content in 3-4 days, avoiding further aflatoxin contamination.

\subsection{A. flavus and aflatoxin determination}

A random sample of 300 pods were hand shelled, out of which a random sub-sample of 100 seeds was tested in the laboratory to assay for percent infection by Aspergillus
(Waliyar and Zambettakis, 1979). More than $90 \%$ of the soil fungal population was A. flavus, and other species (e.g. A. niger, A. parasiticus, Penicillium spp., Rhizopus spp.) were only present occasionally. In brief, seeds were surface sterilized by soaking for $3 \mathrm{~min}$ in a $0.1 \%$ aqueous solution of mercuric chloride, and were rinsed three times with sterile distilled water and placed on a filter paper in $10 \mathrm{~cm}$ diameter sterile Petri dishes at $25^{\circ} \mathrm{C}$. To maintain high humidity, 1 to

Table 1

Rainfall between sowing and harvest, irrigation applied, calculated evaporation, and calculated fraction extractable soil water (FESW) between flowering and harvest (FL to H), and in the 25 days before harvest (H-25 days) in experiments conducted between 1991 and 1994 at the Sahelian Centre, Sadore, Niger

\begin{tabular}{|c|c|c|c|c|c|c|}
\hline \multirow[t]{2}{*}{ Sowing date } & \multirow[t]{2}{*}{ Irrigation treatment } & \multirow[t]{2}{*}{ Rainfall (mm) } & \multirow[t]{2}{*}{ Irrigation applied (mm) } & \multirow[t]{2}{*}{ Evaporation (mm) } & \multicolumn{2}{|l|}{ FESW } \\
\hline & & & & & $\mathrm{Fl}$ to $\mathrm{H}$ & H-25 days \\
\hline \multicolumn{7}{|l|}{1991} \\
\hline \multirow[t]{4}{*}{1} & 7 days & 500 & 300 & 563 & 0.86 & 0.86 \\
\hline & 14 days & 500 & 160 & 563 & 0.78 & 0.71 \\
\hline & 21 days & 500 & 80 & 563 & 0.77 & 0.71 \\
\hline & Rainfed & 500 & 0 & 563 & 0.74 & 0.65 \\
\hline \multirow[t]{4}{*}{2} & 7 days & 430 & 280 & 591 & 0.79 & 0.59 \\
\hline & 14 days & 430 & 140 & 591 & 0.71 & 0.45 \\
\hline & 21 days & 430 & 80 & 591 & 0.69 & 0.37 \\
\hline & Rainfed & 430 & 0 & 591 & 0.65 & 0.37 \\
\hline \multirow[t]{4}{*}{3} & 7 days & 246 & 220 & 455 & 0.66 & 0.51 \\
\hline & 14 days & 246 & 120 & 455 & 0.52 & 0.35 \\
\hline & 21 days & 246 & 80 & 455 & 0.49 & 0.28 \\
\hline & Rainfed & 246 & 0 & 455 & 0.39 & 0.14 \\
\hline \multirow[t]{4}{*}{4} & 7 days & 225 & 220 & 487 & 0.58 & 0.48 \\
\hline & 14 days & 225 & 120 & 487 & 0.46 & 0.41 \\
\hline & 21 days & 225 & 80 & 487 & 0.38 & 0.32 \\
\hline & Rainfed & 225 & 0 & 487 & 0.27 & 0.23 \\
\hline \multicolumn{7}{|l|}{1992} \\
\hline \multirow[t]{4}{*}{1} & 7 days & 456 & 320 & 705 & 0.79 & 0.43 \\
\hline & 14 days & 456 & 160 & 705 & 0.69 & 0.29 \\
\hline & 21 days & 456 & 100 & 705 & 0.61 & 0.16 \\
\hline & Rainfed & 456 & 0 & 705 & 0.58 & 0.14 \\
\hline \multirow[t]{4}{*}{2} & 7 days & 401 & 240 & 633 & 0.61 & 0.29 \\
\hline & 14 days & 401 & 100 & 633 & 0.49 & 0.13 \\
\hline & 21 days & 401 & 60 & 633 & 0.44 & 0.10 \\
\hline & Rainfed & 401 & 0 & 633 & 0.42 & 0.09 \\
\hline \multicolumn{7}{|l|}{1993} \\
\hline \multirow[t]{4}{*}{1} & 7 days & 408 & 280 & 578 & 0.80 & 0.67 \\
\hline & 14 days & 408 & 140 & 578 & 0.69 & 0.50 \\
\hline & 21 days & 408 & 100 & 578 & 0.66 & 0.41 \\
\hline & Rainfed & 408 & 0 & 578 & 0.58 & 0.30 \\
\hline \multirow[t]{4}{*}{2} & 7 days & 304 & 280 & 662 & 0.63 & 0.43 \\
\hline & 14 days & 304 & 140 & 662 & 0.51 & 0.28 \\
\hline & 21 days & 304 & 80 & 662 & 0.39 & 0.12 \\
\hline & Rainfed & 304 & 0 & 662 & 0.37 & 0.10 \\
\hline \multicolumn{7}{|l|}{1994} \\
\hline \multirow[t]{4}{*}{1} & 7 days & 608 & 260 & 591 & 0.81 & 0.64 \\
\hline & 14 days & 608 & 120 & 591 & 0.73 & 0.48 \\
\hline & 21 days & 608 & 80 & 591 & 0.68 & 0.46 \\
\hline & Rainfed & 608 & 0 & 591 & 0.68 & 0.46 \\
\hline \multirow[t]{4}{*}{2} & 7 days & 469 & 220 & 571 & 0.69 & 0.43 \\
\hline & 14 days & 469 & 100 & 571 & 0.57 & 0.34 \\
\hline & 21 days & 469 & 60 & 571 & 0.50 & 0.35 \\
\hline & Rainfed & 469 & 0 & 571 & 0.50 & 0.35 \\
\hline
\end{tabular}


$2 \mathrm{~mL}$ of distilled water was added every day during the first 5 days. After 7 days, the number of seeds contaminated by Aspergillus was counted.

For each treatment in 1992 and 1993 aflatoxin content was measured using an enzyme linked immuno-sorbent assay (ELISA: Transia Society, France) technique (Waliyar et al., 1994) in a bulk sample from the three replications. HPLC was used to verify ELISA data. In 1994, aflatoxin content was measured in each replicate. Aflatoxin content was not measured in 1991. For each analysis, $100 \mathrm{~g}$ of seed was randomly picked and ground in a mill. A $20 \mathrm{~g}$ subsample was then extracted in an aqueous methanol solution $(80 \% \mathrm{v} / \mathrm{v})$. Into this sub-sample, $60 \mathrm{~mL}$ of methanol solution was added. The sample was then homogenized at high speed for $3 \mathrm{~min}$ and filtered using a Whatman No. 1 filter. To determine aflatoxin concentration from each dilution $(1: 15$, $1: 75$ and 1:375), $50 \mu$ l of diluted extracts were placed in duplicates into the wells. The optical density was read at a wavelength of $450 \mathrm{~nm}$ with the aid of a micro-titration plate reader.

Analysis of variance was carried out for each year separately using raw data (pod yield and aflatoxin) or angular transformed values (percentage infection) using Genstat 5 (Genstat 5 Committee, 1987). Pod yield data was fairly variable, and original replicate data was re-checked to confirm values, resulting in missing values being substituted for observed values in four plots.
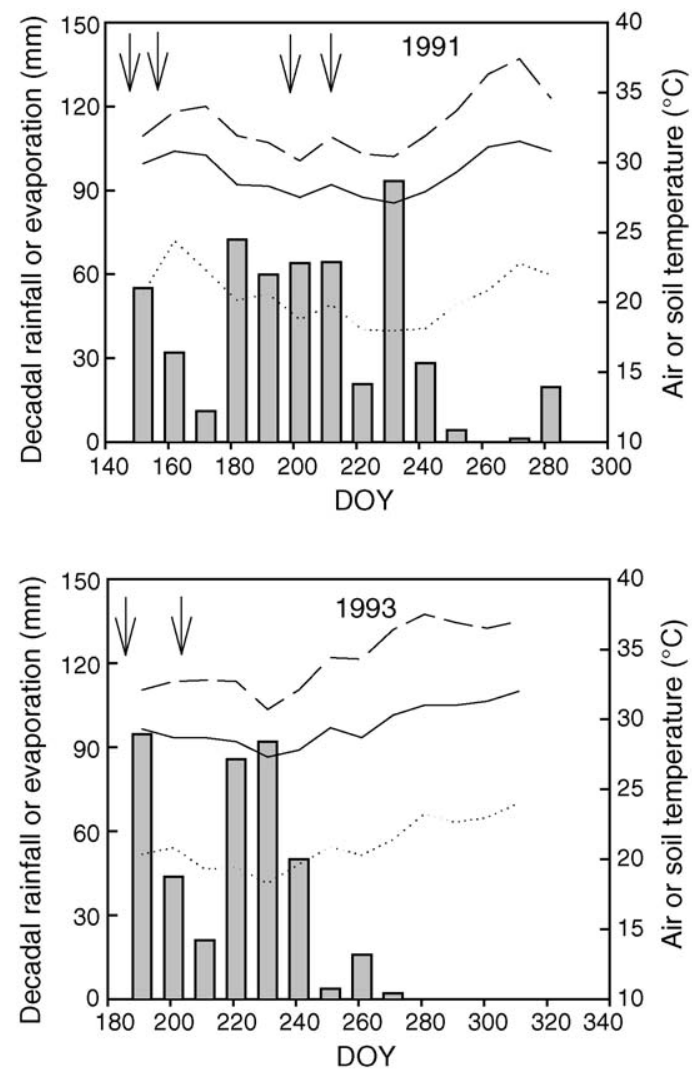

\subsection{Prediction of soil water balance}

CROPGRO-peanut model was calibrated using genetic coefficients for cv. 55-437, a short duration Spanish type similar to JL24, using the observed experimental and site (soil characteristics and weather) data to simulate total dry weight and pod yield using procedures described in Boote et al. (1998) and Hunt and Boote (1998). The drained upper and lower limits were 0.132 and $0.058 \mathrm{~cm}^{3} \mathrm{~cm}^{-3}$, respectively, and the soil depth was $0.6 \mathrm{~m}$, giving $44 \mathrm{~mm}$ available water. Key parameters include the cultivar genetic coefficients for phenology (timing of vegetative and reproductive stages), growth, pod addition rate and pod yield. Daily rainfall, air and soil temperature, radiation and pan evaporation were obtained from the weather station at Sadore. The model was calibrated on the whole data set to give the best prediction of phenology and pod yield. Once the model was calibrated, the average fraction of extractable soil water (FESW) in the root zone between flowering and harvest, or in the last 40-25 days of the growing season, in each of the 40 'environments' was calculated using the simulated daily soil water content and available water content. Rates of change in FESW were also calculated, but as durations from flowering to harvest were mostly similar, and irrigation was applied at 7-21 days intervals, this approach did not improve predictions.
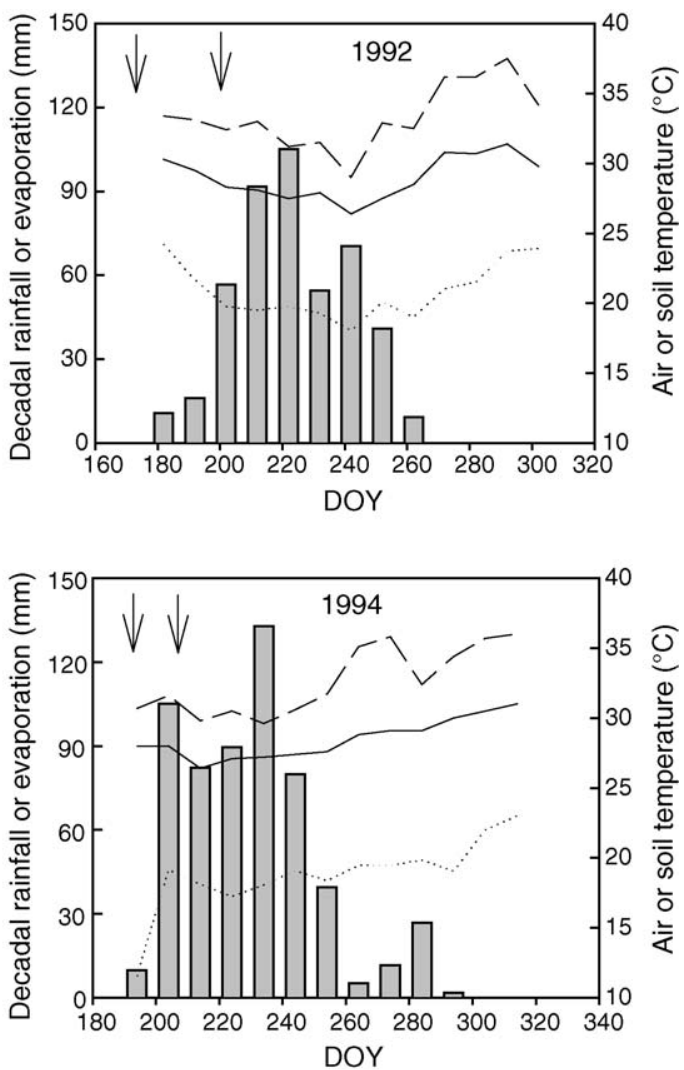

Fig. 1. Decadal values of total rainfall (bars) and evaporation (long-dashed line), and average air (solid line) and soil (dotted line) temperature at Sadore, Niger between 1991 and 1994. Arrows show planting dates in each year. 
Table 2

Effect of sowing date and irrigation treatment on observed days to 50\% flowering, number of plants at harvest, pod yield, A. flavus infection (transformed values in parenthesis) and aflatoxin concentration in cv. JL24 during 1991-1994

\begin{tabular}{|c|c|c|c|c|c|c|}
\hline Sowing date & $\begin{array}{l}\text { Irrigation } \\
\text { treatment }\end{array}$ & $\begin{array}{l}\text { Days to } 50 \% \\
\text { flowering }\end{array}$ & $\begin{array}{l}\text { No. plants at } \\
\text { harvest }\left(\mathrm{m}^{2}\right)\end{array}$ & $\begin{array}{l}\text { Pod yield } \\
\left(\mathrm{kg} \mathrm{ha}^{-1}\right)\end{array}$ & $\begin{array}{l}\% \text { A. flavus } \\
(\operatorname{arcsine} \%)\end{array}$ & $\begin{array}{l}\text { Aflatoxin } \\
\left(\mu \mathrm{g} \mathrm{kg}^{-1}\right)\end{array}$ \\
\hline \multicolumn{7}{|l|}{1991} \\
\hline \multirow[t]{4}{*}{1} & 7 days & 30 & 17.4 & 1061 & $26(30)$ & $\mathrm{a}$ \\
\hline & 14 days & 30 & 16.5 & 722 & $33(35)$ & $\mathrm{a}$ \\
\hline & 21 days & 27 & 17.8 & 945 & 39 (39) & $\mathrm{a}$ \\
\hline & Rainfed & 29 & 16.3 & 1315 & $51(46)$ & $\mathrm{a}$ \\
\hline \multirow[t]{4}{*}{2} & 7 days & 34 & 6.3 & 332 & $34(36)$ & a \\
\hline & 14 days & 38 & 4.1 & 211 & $43(41)$ & a \\
\hline & 21 days & 32 & 5.8 & 242 & $49(44)$ & a \\
\hline & Rainfed & 37 & 6.7 & 491 & $59(51)$ & $\mathrm{a}$ \\
\hline \multirow[t]{4}{*}{3} & 7 days & 32 & 7.1 & 295 & $41(40)$ & $\mathrm{a}$ \\
\hline & 14 days & 32 & 8.2 & 147 & $50(45)$ & $\mathrm{a}$ \\
\hline & 21 days & 31 & 6.4 & 171 & $54(47)$ & $\mathrm{a}$ \\
\hline & Rainfed & 34 & 6.7 & 194 & $67(55)$ & $\mathrm{a}$ \\
\hline \multirow[t]{5}{*}{4} & 7 days & 37 & 8.4 & 316 & $52(46)$ & $\mathrm{a}$ \\
\hline & 14 days & 27 & 7.6 & 153 & $59(50)$ & $\mathrm{a}$ \\
\hline & 21 days & 28 & 9.6 & 170 & $66(54)$ & $\mathrm{a}$ \\
\hline & Rainfed & 27 & 8.7 & 247 & $78(62)$ & $\mathrm{a}$ \\
\hline & $\operatorname{SED}(9,24 \text { d.f. })^{b}$ & 2.2 & 1.13 & 101.1 & $5.3(3.3)$ & - \\
\hline \multicolumn{7}{|l|}{1992} \\
\hline \multirow[t]{4}{*}{1} & 7 days & 31 & 2.5 & 581 & $19(26)$ & 73 \\
\hline & 14 days & 33 & 3.1 & 579 & $23(29)$ & 91 \\
\hline & 21 days & 29 & 4.4 & 750 & $33(35)$ & 111 \\
\hline & Rainfed & 33 & 4.4 & 1231 & $47(43)$ & 152 \\
\hline \multirow[t]{5}{*}{2} & 7 days & 28 & 3.3 & 238 & $30(33)$ & 78 \\
\hline & 14 days & 26 & 2.4 & 56 & $44(42)$ & 125 \\
\hline & 21 days & 28 & 4.1 & 112 & $61(51)$ & 149 \\
\hline & Rainfed & 28 & 2.9 & 142 & $81(64)$ & 197 \\
\hline & SED (3, 8 d.f.) & 1.8 & 0.54 & 216.4 & $2.2(1.5)$ & $\mathrm{c}$ \\
\hline \multicolumn{7}{|l|}{1993} \\
\hline \multirow[t]{4}{*}{1} & 7 days & 25 & 8.7 & 129 & $22(28)$ & 34 \\
\hline & 14 days & 25 & 9.2 & 118 & $28(32)$ & 45 \\
\hline & 21 days & 24 & 10.1 & 142 & $34(35)$ & 97 \\
\hline & Rainfed & 24 & 10.2 & 130 & $41(40)$ & 120 \\
\hline \multirow[t]{5}{*}{2} & 7 days & 24 & 8.5 & 90 & $39(38)$ & 34 \\
\hline & 14 days & 24 & 7.3 & 57 & $41(40)$ & 82 \\
\hline & 21 days & 24 & 9.6 & 86 & $51(46)$ & 107 \\
\hline & Rainfed & 24 & 7.3 & 102 & $60(50)$ & 132 \\
\hline & SED (3, 8 d.f.) & 0.4 & 0.57 & 21.4 & $1.4(0.8)$ & $\mathrm{c}$ \\
\hline \multicolumn{7}{|l|}{1994} \\
\hline \multirow[t]{4}{*}{1} & 7 days & 28 & 9.9 & 119 & $21(27)$ & 38 \\
\hline & 14 days & 28 & 9.4 & 110 & $20(27)$ & 38 \\
\hline & 21 days & 28 & 10.5 & 115 & $21(28)$ & 38 \\
\hline & Rainfed & 28 & 9.1 & 107 & $23(28)$ & 38 \\
\hline \multirow[t]{5}{*}{2} & 7 days & 28 & 7.4 & 75 & $27(32)$ & 39 \\
\hline & 14 days & 29 & 7.9 & 74 & $33(35)$ & 41 \\
\hline & 21 days & 29 & 9 & 69 & $42(40)$ & 59 \\
\hline & Rainfed & 28 & 8.6 & 53 & 57 (49) & 208 \\
\hline & $\operatorname{SED}(3,8$ d.f. $)$ & 0.3 & 0.8 & 8.8 & $1.0(0.7)$ & 5.8 \\
\hline
\end{tabular}

a Not analysed.

b SED: standard error of the difference.

c Unreplicated bulk sample. 


\section{Results}

\subsection{Weather}

Total rainfall during the experimental period between 1991 and 1994 ranged from 500 to 608 mm (Table 1, Fig. 1), typical values for Sadore in Niger (Sivakumar et al., 1993). Within individual sowing date $\times$ year combinations, rainfall varied from 225 to $608 \mathrm{~mm}$ and pan evaporation from 455 to $705 \mathrm{~mm}$. Under rainfed conditions pan evaporation exceeded rainfall by $>100 \%$ in some years and only in the first sowing date (S1) in 1994 did rainfall exceed evaporation. Therefore, in some sowing date $\times$ year combinations frequent irrigation meant that excess water may have been applied. Mean daily air and soil temperature during pod-filling averaged $28-30$ and $31-35{ }^{\circ} \mathrm{C}$, respectively, generally increasing towards the end of the season as rainfall declined (Fig. 1). Environmental conditions were therefore well within the range likely to favour aflatoxin concentration.

\subsection{Flowering time, stand counts and pod yield}

JL24 flowered 25-30 days after sowing in most experiments and, with the exception of 1991, irrigation treatments had little effect on flowering time (Table 2). In 1991, flowering times were as late as 38 days, but these delays were not systematically related to irrigation treatment or sowing date. All experiments were harvested around 95100 days after sowing (mean $97 \pm 2.1$ days) except for the third and fourth sowing date in 1991 (75 days) and the first sowing in 1992 (117 days). Therefore, durations from flowering to harvest were similar, between 65 and 70 days.

Experiments were established at 20 plants $\mathrm{m}^{-2}$, but only at the first sowing date in 1991 was final plant sand close to this value (Table 2). Plant stands were generally $<10 \mathrm{~m}^{2}$ and in some cases as low as 2.4 plants $\mathrm{m}^{-2}$. Clearly drought, and probably nematodes (Sharma et al., 1992; Waliyar et al., 1992) had a substantial effect on stand establishment. However, there was no relation $\left(r^{2}=0.13\right)$ between pod yield and stand count.
There were significant effects of sowing date on pod yield in all years and significant effects of irrigation frequency in 1991 only (Table 3). There were no significant sowing date $\times$ irrigation interactions. Pod yields were quite variable, with rainfed plot yields often exceeding that of plots receiving supplementary irrigation. Pod yield varied with year and sowing date, from $1315 \mathrm{~kg} \mathrm{ha}^{-1}$ at the first sowing date (S1) in 1991 down to $53 \mathrm{~kg} \mathrm{ha}^{-1}$ at S2 in 1994 (Table 3). Delayed sowing always reduced pod yield but there was no consistent effect of irrigation treatment on pod yield.

The model predicted phenology and yields of the whole data set reasonably well (Fig. $2 ; r^{2}=0.67, P<0.001$, $n=40$ ), with a root mean square deviation (RMSD) of $244 \mathrm{~kg} \mathrm{ha}^{-1}$. The rainfed pod yield at S1 1992 (circled in Fig. 2) was much higher than predicted and without this point $r^{2}=0.78$. Predicted yields for three irrigation treatments at S1 and S2 in 1991 were noticeably higher than observed yields.

\subsection{Aspergillus infection and aflatoxin concentration}

There were significant effects of irrigation and sowing date on Aspergillus infection in all years (Table 3). There were also significant sowing date $\times$ irrigation interactions in 1992 and 1994. The percent infection with Aspergillus (untransformed) ranged from 19 to $81 \%$ (Table 2). Generally, infection was higher in 1991 and lower in 1994, and it increased with late sowing. For example, in 1991 mean percent infection was 37, 46, 53 and 63 in S1 to S4, respectively. Likewise, infection increased as the irrigation frequency declined from 7-day intervals to none (rainfed). For example, in S1 in 1991, infection was 26, 33, 39 and $51 \%$ at 7,14 and 21 days intervals, and rainfed, respectively.

Aflatoxin concentration was not measured in 1991 but between 1992 and 1994 values ranged from 34 to $208 \mu \mathrm{g} \mathrm{kg}^{-1}$. In 1994, the only year in which replicate values were analysed, there were significant effects of sowing date, irrigation and their interaction (Table 3). Aflatoxin concentration was affected by year, sowing date and irrigation treatment in a similar manner to Aspergillus and there was a good relation $\left(r^{2}=0.71, P<0.001, n=24\right)$

Table 3

Mean sums of squares for replicate (Rep.), irrigation and sowing date (Date) effects on pod yield, percentage infection with Aspergillus (\%A. flavus, angular transformed) and aflatoxin (1994 only) in cv. JL24 in 1991-1994

\begin{tabular}{|c|c|c|c|c|c|c|c|c|c|c|c|}
\hline & \multicolumn{3}{|c|}{1991} & \multicolumn{3}{|c|}{1992} & \multicolumn{2}{|l|}{1993} & \multicolumn{3}{|l|}{1994} \\
\hline & d.f. & Pod yield & \%A. flavus & d.f. & Pod yield & $\%$ A. flavus & Pod yield & \%A. flavus & Pod yield & $\%$ A. flavus & Aflatoxin \\
\hline Rep. & 2 & 263608 & 82 & 2 & 308410 & 7 & 421 & 5 & 60 & 14 & 225 \\
\hline Irrigation & 3 & $1780135^{\text {*** }}$ & $516^{* *}$ & 3 & 149828 & $666^{* * * *}$ & 1038 & $169^{* * * *}$ & 301 & $106^{* * * *}$ & $9966^{* * * *}$ \\
\hline Residual & 6 & 13590 & 35 & 6 & 121179 & 6 & 1919 & 2 & 367 & $<1$ & 86 \\
\hline Date & 3 & $1780135^{\text {*** }}$ & $526^{* * * *}$ & 1 & $2522827^{* *}$ & $1228^{* * * *}$ & $12604^{* *}$ & $596^{* * * *}$ & $12178^{* * *}$ & $807^{* * * *}$ & $14123^{* * *}$ \\
\hline Date $\times$ irrigation & 9 & 34209 & $<1$ & 3 & 151660 & $50^{*}$ & 327 & 3 & 78 & $72^{* * * *}$ & $9808^{* * *}$ \\
\hline Residual & 24 & 36345 & 33 & 8 & 159813 & 9 & 842 & 2 & 96 & 3 & 117 \\
\hline Total & 47 & & & 23 & & & & & & & \\
\hline
\end{tabular}

* Significance at $P<0.05$.

** Significance at $P<0.01$.

*** Significance at $P<0.001$. 


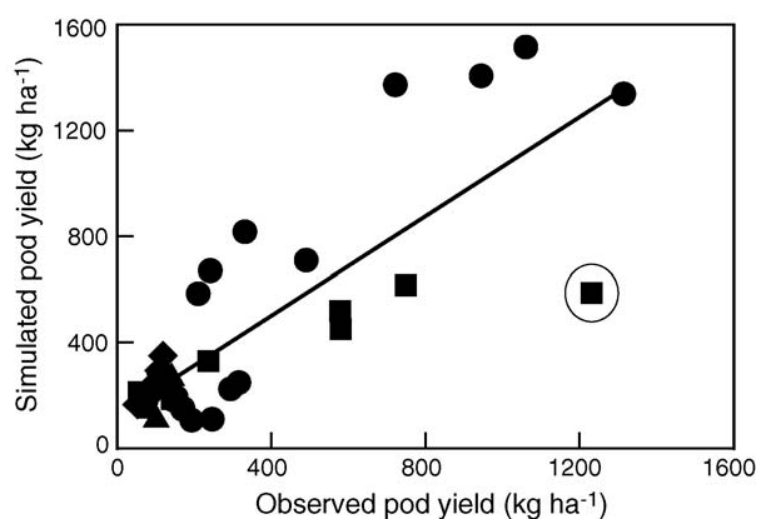

Fig. 2. Relation between simulated and observed pod yields of cv. JL 24 with CROPGRO-peanut model across all sowing dates and irrigation treatments during 4 years (1991 through 1994): $Y=125.8+0.94 X$ $\left(r^{2}=0.67 ; P<0.001 ; n=40\right)$. Key to symbols: $\mathbf{O}, 1991 ; \mathbf{\Delta}, 1992$; $1993 ; \bullet, 1994$.

between aflatoxin concentration and percent infection (Fig. 3).

\subsection{Pod yield, crop water use and FESW}

Simulated crop water use varied from $193 \mathrm{~mm}$ at $\mathrm{S} 1$ in 1991 to only $44 \mathrm{~mm}$ at S4 in 1991 and S2 in 1992. As a proportion of total water use (plant and soil evaporation, deep drainage and runoff), these values represented between 34 and $<10 \%$ of total water use. Crop water use was noticeably higher at S1 and S2 in 1991 (>100 mm) than in other years and sowing dates (all $<100 \mathrm{~mm}$ ). Rainfall was well distributed in 1991 (Fig. 1) and early sowings suffered no periods of prolonged drought nor periods of excessive rainfall which would have checked plant growth and hence limited crop water use. Across years, sowing dates and

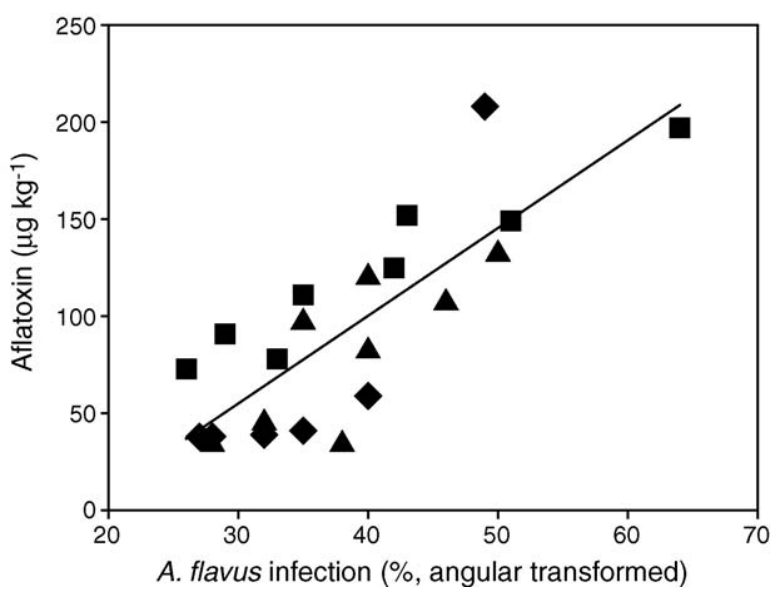

Fig. 3. Relation between observed aflatoxin concentration and Aspergillus infection across all sowing dates and irrigation treatments during 3 years (1992 through 1994): $=-90.3+4.73 X\left(r^{2}=0.71 ; P<0.001 ; n=24\right)$. Key to symbols: $\mathbf{\Lambda}, 1992 ; \boldsymbol{\square}, 1993 ;-1994$.

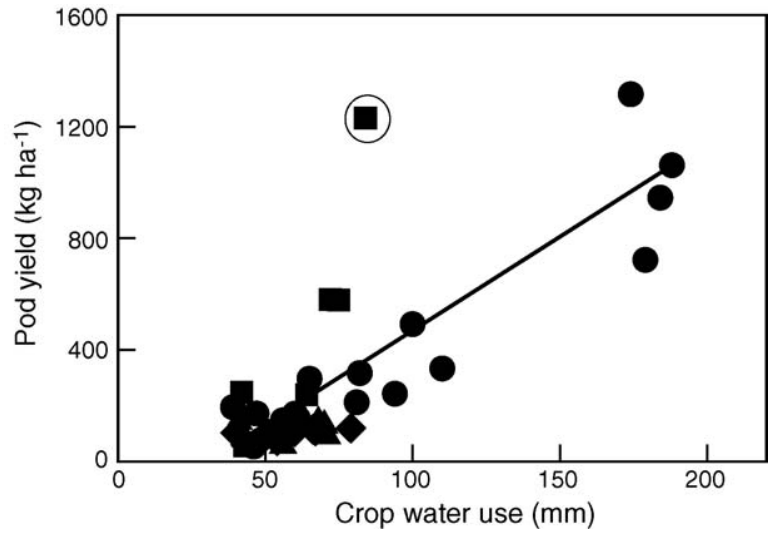

Fig. 4. Relation between observed pod yield and simulated crop water use across all sowing dates and irrigation treatments during 4 years (1991 through 1994): $Y=-203.1+6.7 X\left(r^{2}=0.62 ; P<0.001 ; n=40\right)$. Key to symbols:, $1991 ; \boldsymbol{\Delta}, 1992 ; \boldsymbol{\square}, 1993 ; \bullet, 1994$.

irrigation treatments there was a good relation $\left(r^{2}=0.62\right.$, $P<0.001, n=40)$ between pod yield and simulated crop water use $\left(r^{2}=0.75\right.$ without rainfed S2 in 1992, circled point in Fig. 4), though as noted previously pod yields were lower than predicted in some treatments (e.g. S1 in 1991).

The simulated fraction of extractable soil water (FESW) between flowering and harvest ranged from 0.86 to 0.27 (Table 1). In the last 25 days of the season values of FESW ranged from 0.86 to 0.09 . Across all sowing dates, FESW was greater and soil moisture conditions therefore more favourable with more frequent irrigation. However, in all years FESW was lower with later sowing. If stress is defined as FESW $<0.50$, then most treatments experienced some degree of drought stress, particularly towards the end of the season, despite irrigation. For example, at S1 in 1991, where decadal rainfall totals were between 20 and $70 \mathrm{~mm}$ in all

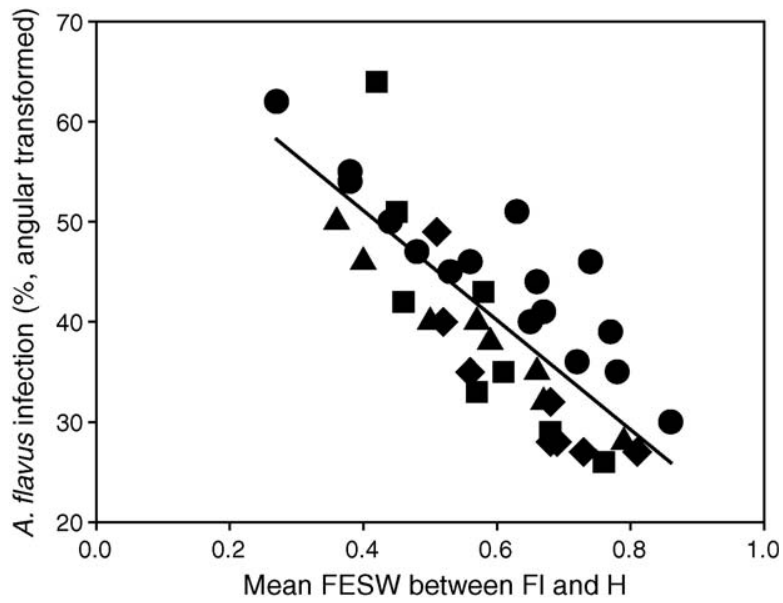

Fig. 5. Relation between observed Aspergillus infection and average simulated fraction of extractable soil water (FESW) between flowering (FL) and harvest $(\mathrm{H})$ across all sowing dates and irrigation treatments during 4 years (1991 through 1994): $Y=72.5-53.0 X \quad\left(r^{2}=0.62 ; \quad P<0.001\right.$; $n=40)$. Key to symbols: $\mathbf{O}, 1991 ; \mathbf{\Delta}, 1992 ; \mathbf{\square}, 1993 ; \boldsymbol{\rangle}, 1994$. 


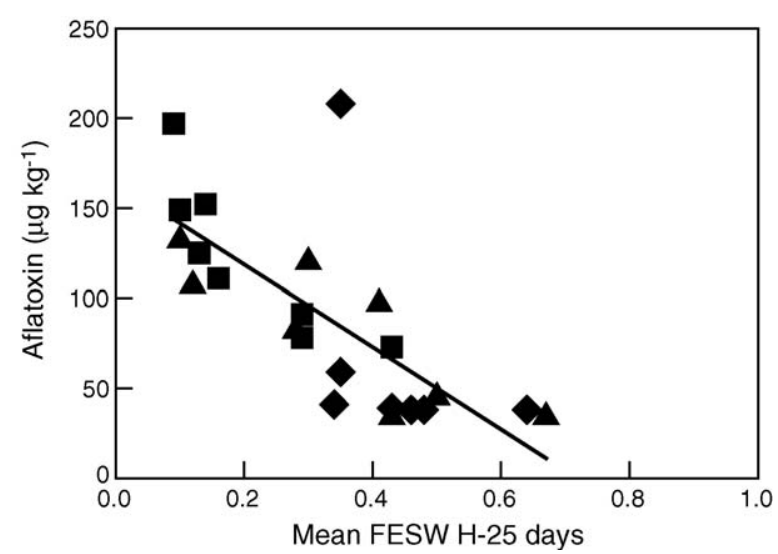

Fig. 6. Relation between observed aflatoxin concentration and average simulated fraction of extractable soil water (FESW) in the last 25 days of pod-filling (H-25 days) across all sowing dates and irrigation treatments during 3 years (1992 through 1994): $Y=164.4-228.9 X \quad\left(r^{2}=0.54\right.$; $P<0.001 ; n=24)$. Key to symbols: $\boldsymbol{\Lambda}, 1992 ; \square, 1993 ;>, 1994$.

periods with no dry spells, FESW remained $>0.6$ and there were only 5 days where FSEW $<0.5$. Therefore, at most only a mild and transient drought occurred at $\mathrm{S} 1$. In contrast, at S4 in 1991 decadal rainfall totals were between 0 and $30 \mathrm{~mm}$, there were 22 days where FESW $<0.5$ and drought was therefore severe.

\subsection{Aspergillus infection, aflatoxin concentration and FESW}

The year, sowing date and irrigation treatments created a wide range of water stress conditions (Table 1), which were reflected in the low yields and low simulated crop water use. Values of percentage infection with A. flavus (angular transformed) were most strongly negatively related to average FESW between flowering and harvest (Fig. 5; $\left.r^{2}=0.62, P<0.001, n=40\right)$; relations with FESW in the last 40 or 25 days of pod-filling accounted for half the variation of that between flowering and harvest. Aflatoxin concentration (in 1992-94 only) was also negatively related to FESW (Fig. 6; $r^{2}=0.54, P<0.001, n=24$ ), though in contrast to A. flavus the greatest proportion of variance was accounted for by FESW in the last 25 days of pod-filling. Thus, when water stress during pod-filling was severe, infection and aflatoxin concentration were high.

\section{Discussion}

The range in rainfed pod yields, from 53 to $1315 \mathrm{~kg} \mathrm{ha}^{-1}$, observed across this 4-year field study is typical for peanuts in semi-arid to arid climates (e.g. Ntare and Williams, 1998), and illustrates the variable, and harsh conditions under which small-scale subsistence farmers labour in countries such as Niger. A small delay in planting after the first rains in any given year substantially increased the risk of drought and hence reduced pod yield. Later sowings may also have established less well because of de-nitrification after the first rains. Indeed, in 1993 and 1994 pod yields hardly exceeded the amount of seed planted, typically $100 \mathrm{~kg} \mathrm{ha}^{-1}$. Yield was not related to rainfall totals, with the lowest pod yields occurring in the wettest year (1994), showing that rainfall distribution and evaporative demand is far more important (Dancette and Forest, 1986).

Pod yields across all treatments in this study were variable (mean $306 \mathrm{~kg} \mathrm{ha}^{-1}$, RMSD $244 \mathrm{~kg} \mathrm{ha}^{-1}$ ) and in a number of years pod yields were higher in rainfed than irrigated plots, with pod yield at S1 in 1992 anomalously high. Simulations suggested that irrigated pod yields should have been higher than those observed, particularly in 1991 . Although stand counts were low in most experiments, variation in pod yield was not strongly associated with stand count within or across years, and using stand count as a covariate did not reduce variability in pod yield. Previous studies have shown that nematodes cause considerable variation in groundnut growth at this site (Sharma et al., 1992; Waliyar et al., 1992). Peanuts are also sensitive to excess soil moisture and frequent irrigation may have contributed to water logging and lower yields as well (Ibrahim et al., 2002) in some treatments/years. As nematodes were not controlled in these experiments, the usual practice at this site, it is probably that the combination of drought, high soil temperature, water logging and nematodes caused variable stand counts and growth.

CROPGRO-peanut simulated pod yields reasonably well, excluding rainfed S2 in 1991. Across all years and sowings observed pod yields were broadly related to simulated crop water use (transpiration) and the amounts of water used were typical of peanuts growing in semi-arid environments (Azam-Ali et al., 1989; Dancette and Forest, 1986). Ideally it would have been useful to have some soil moisture data to verify these simulations, but CROPGRO models have been widely tested and verified, including in semi-arid, northern Ghana (Naab et al., 2004). Within sowing dates simulated crop water use often did not vary much and FESW would appear to be a much better discriminator of stress. Many crop simulation models use FESW (or fraction of transpirable soil water, fraction of available soil water) as there is a consistency in plant responses across a wide of conditions (Sinclair et al., 1987) and as such FESW is a useful physiological (stress) index.

Drought and high soil temperature were common occurrences, especially when sowing was delayed, giving rise to ideal conditions for infection and aflatoxin contamination (Cole et al., 1989; Sanders et al., 1993; Parmar et al., 1997; Marin et al., 1998). In the experiments reported here infection was widespread and aflatoxin was found at concentrations $>30 \mu \mathrm{g} \mathrm{kg}^{-1}$ at all treatments in 1992-1994 when average FESW in the last 25 days of podfilling was between 0.09 and 0.67 and average soil temperatures (at the nearly meteorological station) were between 31 and $35^{\circ} \mathrm{C}$. Unfortunately aflatoxin was not measured in 1991 when values of FESW were generally 
higher and there should therefore have been less contamination. Previous studies have shown that a combination of $>20$ days stress at the end of the season with soil temperatures of 29 to $31{ }^{\circ} \mathrm{C}$ results in aflatoxin contamination. This is associated with stress reducing kernel water activity $\left(K_{\mathrm{aw}}\right)$ or internal RH to values between 0.85 and 0.95 (Dorner et al., 1989); when $K_{\text {aw }}>0.95$ phytoalexins prevent contamination and when $K_{\mathrm{aw}}<0.85 \mathrm{~A}$. flavus does not grow or produce toxin.

In the experiments reported here stress durations (FESW $<0.5)$ were sometimes as short as 8 days. Nonetheless contamination occurred. Given adequate inoculum, infection with Aspergillus and contamination with aflatoxin can occur within a short period of time. For example, Diener and Davis (1967) reported the minimum time for aflatoxin production under optimal conditions is about $60 \mathrm{~h}$. The $A$. flavus strain in Niger is also highly toxigenic (Waliyar, unpublished). Thus $>20$ days drought and high soil temperature stress are probably not necessary for contamination as long as the physiological conditions determining $K_{\text {aw }}$ are met in some pods - principally immature or damaged pods. So even $<10$ days stress was enough to cause significant aflatoxin contamination. Nonetheless, it is clear that the longer and more severe the stress, the greater are levels of infection and contamination.

CROPGRO-peanut model successfully estimated pod yields over the 40 environments used in this experiment, and simulated crop water use and FESW account for a high proportion of the observed variation in pod yield, infection and contamination. Assuming that soil temperatures are favourable for A. flavus and aflatoxin production, i.e. around $30{ }^{\circ} \mathrm{C}$, then mean FESW from podding to harvest or the last 25 days of pod-filling could be used to predict infection and contamination, respectively, given basic crop data (flowering, podding and maturity dates), agronomic data (sowing date, soil water holding capacity and soil type) and weather data. Where soil temperatures are outside the optimal range then soil temperature will probably be needed as a model input as well. This is the first time that we are aware of where field observations have been successfully modelled in West Africa. Nageswara Rao et al. (2004) have used a similar approach to model the risk of contamination in Queensland, using the crop simulation model APSIM to 'count' the number of stress days, which is then related to risk. These simple empirical relations provide the basis for a decisionsupport system (DSS) that can be used by pathologists and other crop scientists to predict infection and contamination in the field in environments where aflatoxin is a serious problem. A good example of a DSS is the DON-forecasting system in Canada (Hooker et al., 2002). These support systems will allow areas historically at high risk, as well as areas potentially at risk in the coming season, to be targeted for technology transfer, e.g. of possible ameliorating practices such as earlier harvesting or even supplementary irrigation if available, as well as the promotion of greater awareness of the health risks of aflatoxin. Nageswara Rao et al. (2004) have shown how farmers in Queensland can manage aflatoxin given a DSS.

In conclusion, this study has shown that infection and contamination occurred in the field in Niger even when stress periods were short. Infection and contamination can be predicted in peanuts using the fraction of extractable soil water when soil temperatures are not limiting aflatoxin contamination. These relations can form the basis of a decision-support system for aflatoxin risk prediction.

\section{References}

Azaizeh, H.A., Pettit, R.E., Smith, O.D., Taber, R.A., 1989. Reaction of peanut genotypes under drought stress to Aspergillus flavus and A. parasiticus. Peanut Sci. 16, 109-113.

Azam-Ali, S.N., Simmonds, L.P., Nageswara Rao, R.C., Williams, J.H., 1989. Population, growth and water use of groundnut maintained on stored water. Part III. Dry matter, water use and light interception. Exp. Agric. 25, 77-86.

Bhat, R.V., Vasanthi, S., 2003. Food Safety in Food Security and Food Trade: Mycotoxin Food Safety Risk in Developing Countries. FOCUS 10, Brief 3 of 17, September 2003. International Food Policy Research Institute, Washington, DC, USA.

Blankenship, P.D., Cole, R.J., Sanders, T.H., Hill, R.A., 1984. Effect of geocarposphere temperature on pre-harvest colonization of droughtstressed peanuts by Aspergillus flavus and subsequent aflatoxin concentration. Mycopathologia 85, 69-74.

Boote, K.J., Jones, J.W., Hoogenboom, G., Pickering, N.B., 1998. The CROPGRO model for grain legumes In: Tsuji, G., Hoogenboom, G., Thornton, P.K. (Eds.), Understanding Options for Agricultural Production. Kluwer Academic Publishers, Dordrecht, The Netherlands, pp. 99-128.

Challinor, A.J., Wheeler, T.R., Craufurd, P.Q., Slingo, J.M., Grimes, D.I.F., 2004. Design and optimisation of a large-area process-based model for annual crops. Agric. Forest Meteorol. 124, 99-120.

Cole, R.J., Sanders, T.J., Dorner, J.W., Blankenship, P.D., 1989. Environmental conditions required to induce pre-harvest concentration in groundnut. Summary of six years research. In: Proceedings of International Workshop on Aflatoxin Concentration in Groundnut. International Crops Research Institute for the Semi-Arid Tropics, Patancheru, India, 6-9 October, 1987, 279-287.

Cole, R.J., Sanders, T.J., Hill, R.A., Blankenship, P.D., 1985. Mean geocarposphere temperatures that induce preharvest aflatoxin concentration of peanuts under drought stress. Mycopathologia 91, 41-46.

Dancette, C., Forest, F., 1986. Alimentation en eau de l'arachide en zone tropicale semi-aride. In: Proceedings of an International Symposium on Agrometeorology of Groundnut. ICRISAT Sahelian Centre, Niamey, 69-98.

D'Mello, J.P.F., 2003. Mycotoxins in cereal grains, nuts and other plant products. In: D’Mello, J.P.F. (Ed.), Food and Safety: Contaminants and Toxins. CABI, Wallingford, UK, pp. 65-90.

Diener, U.L., Davis, N.D., 1967. Limiting temperature and relative humidity for growth and production of aflatoxin and free fatty acids by Aspergillus flavus in sterile peanuts. J. Am. Oil Chem. Soc. 44, 259-263.

Dorner, J.W., Cole, R.J., Sanders, T.H., Blankenship, P.D., 1989. Interrelationship of kernel water activity, soil temperature, maturity and phytoalexin production in pre-harvest aflatoxin concentration of drought-stressed peanuts. Mycopathologia 105, 117-128.

Genstat 5 Committee, 1987. Genstat 5 Reference Manual. Clarendon Press, Oxford.

Gong, Y., Egal, S., Hounsa, A., Turner, P., Hall, A., Cardwell, K., Wild, C., 2003. Determinants of aflatoxin exposure in young children from Benin and Togo West Africa: the critical role of weaning. Int. J. Epidemiol. 32, $556-562$. 
Hall, A.J., Wild, C.P., 2003. Liver cancer in low and middle income countries: prevention should target vaccination, contaminated needles and aflatoxins. Br. Med. J. 326, 994-995.

Hooker, D.C., Schaafsma, A.W., Tamburic-Ilincic, L., 2002. Using weather variables pre-and post-heading to predict deoxynivalenol in winter wheat. Plant Dis. 86, 610-611.

Hunt, L.A., Boote, K.J., 1998. Data for model operation, calibration and evaluation. In: Tsuji, G., Hoogenboom, G., Thornton, P.K. (Eds.), Understanding Options for Agricultural Production. Kluwer Academic Publishers, Dordrecht, The Netherlands, pp. 9-39.

Ibrahim, A.A., Stigter, C.J., Adam, H.S., Adeeb, A.M., 2002. Water-use efficiency of sorghum and groundnut under traditional and current irrigation in the Gezira scheme, Sudan. Irrigation Sci. 21, 115-125.

Marin, S., Sanchis, V., Saenz, R., Ramos, A., Vinas, I., Magan, N., 1998. Ecological determinants for germination and growth of some Aspergillus and Penicillium spp. from maize grain. J. Appl. Microbiol. 84, 2536.

Naab, J.B., Singh, P., Boote, K.J., Jones, J.W., Marfo, K.O., 2004. Evaluation of CROPGRO-peanut model for quantifying yield gaps of groundnut in the Guinean Savanna zone of Ghana. Agron. J. 96, 12311242 .

Nageswara Rao, C.R., Wright, G., Krosch, S., Tatnell, J., 2004. On-farm monitoring and management of aflatoxin contamination in Australia. In: Proceedings of the 4th International Crop Science Congress on New Directions for a Diverse Planet. Brisbane, Australia, 26 September-01 October 2004. Published on CDROM. Website www.cropscience.org.au.

Ntare, B.R., Williams, J.H., 1998. Heritability of components of a simple physiological model for yield in groundnut under semiarid rainfed conditions. Field Crops Res. 58, 25-33.

Parmar, R.S., McClendon, R.W., Hoogenboom, G., Blankenship, P.D., Cole, R.J., Dorner, J.W., 1997. Estimation of aflatoxin concentration in preharvest peanuts using neural networks. Tran. ASAE 40, 809813.

Sanders, T.H., Cole, R.J., Blankenship, P.D., Dorner, J.W., 1993. Aflatoxin concentration of peanuts from plants drought stressed in pod or root zones. Peanut Sci. 20, 5-8.
Sharma, S.B., Waliyar, F., Subramanyam, P., Ndunguru, B.J., 1992. Role of Scutellonema clathricaudatum in etiology of groundnut growth variability in Niger. Plant Soil 143, 133-139.

Sinclair, T.R., Muchow, R.C., Ludlow, M.M., Leach, G.J., Lawn, R.J., Foale, M.A., 1987. Field and model analysis of the effect of water deficits on carbon and nitrogen accumulation by soybean, cowpea and black gram. Field Crops Res. 17, 121-140.

Singh, P., Boote, K.J., Yogeswara Rao, A., Iruthayaraj, M.R., Sheikh, M.A., Hundal, S.S., Narang, R.S., Singh, P., 1994. Evaluation of the groundnut model PNUTGRO for crop response to water availability, sowing dates, and seasons. Field Crops Res. 39, 147-162.

Sivakumar, M.V.K., Maidoukia, A., Stern, R.D., 1993. Agroclimatology of West Africa: Niger, 2nd ed. Information Bulletin no. 5, ICRISAT, Patancheru, India.

Turner, P.C., Mendy, M., White, H., Fortuin, M., Hall, A.J., Wild, C.P., 2000. Hepatitis B infection and aflatoxin biomarker levels in Gambian children. Trop. Med. Int. Health 5, 837-841.

Waliyar, F., Ba, A., Hassan, H., Bonkoungou, S., Bocs, J.P., 1994. Source of resistance to Aspergillus flavus and aflatoxin concentration in groundnut genotypes in West Africa. Plant Dis. 78, 704-708.

Waliyar, F., Ndunguru, B.J., Sharma, S.B., Bationo, A., 1992. Effect of liming and carbofuran on groundnut yield in sandy soils in Niger. Fert. Res. 33, 203-208.

Waliyar, F., Reddy, S.V., Subramaniam, K., Reddy, T.Y., Devi, K.R., Craufurd, P.Q., Wheeler, T.R., 2003a. Importance of mycotoxins in food and feed in India. Aspects Appl. Biol. 68, 147-154.

Waliyar, F., Traoré, A., Fatondji, D., Ntare, B.R., 2003b. Effect of irrigation interval, planting date, and cultivar on Aspergillus flavus and aflatoxin contamination of peanut in a sandy soil of Niger. Peanut Sci. 30, 79-84.

Waliyar, F., Zambettakis, C., 1979. Etude de la mycoflore des gousses et des graines d'arachide au Sénégal. Oléagineux 34, 4.

West, L.T., Wilding, L.P., Landeck, J.K., Calhoun, F.G., 1984. Soil Survey of the ICRISAT Sahelian Centre, Niger, West Africa. Soil and Crop Science Department, Texas A\&M University, College Station, TX, USA and ICRISAT, Patancheru, India.

Wild, C.P., Hall, A.J., 2000. Primary prevention of hepatocellular carcinoma in developing countries. Mutat. Res. 462, 381-383. 